\title{
How far are we in understanding the cause of Parkinson's disease?
}

\author{
Y Ben-Shlomo
}

... the writer will repine at no censure which the precipitate publication of mere conjectural suggestions may incur: but shall think himself fully rewarded by having excited the attention of those, who may point out the most appropriate means of relieving a tedious and most distressing malady.

James Parkinson

It is almost $\mathbf{1 8 0}$ years since James Parkinson described his series of patients with what is now known as Parkinson's disease. His own astute clinical observations were unable to discern any obvious aetiology. "On the subject indeed of remote causes, no satisfactory account has yet been obtained from any of the sufferers." He noted an indulgence in alcohol, lying on damp ground, and the possibility of trauma. He also reported the occupations of three of his patients; one was a gardener, another a sailor, and the third a magistrate. Even in 1817, the disease affected a broad social range of society. We have made some progress in elucidating the cause of Parkinson's disease over this period but this has been limited. For instance, the role of trauma in the aetiology of Parkinson's disease remains uncertain and disputed. ${ }^{2-4}$ Epidemiological research has steadily increased, particularly over the past 10 years, and more research has been directed towards analytical rather than just descriptive studies. More recently, work in the area of genetic epidemiology 5 has begun and researchers are now focusing on both molecular and environmental risk factors. This review interprets the existing evidence and provides a personal view on what we definitively know about the epidemiology of Parkinson's disease, what remains speculative, and what questions remain to be answered.

Department of Epidemiology and Public Health, 1-19 Torrington Place, University College, London Medical School, London WChool, London Y Ben-Shlomo

Correspondence to: Dr Y Ben-Shlomo, Department of Social Medicine, University of Bristol, Canynge Hall, Whiteladies Road, Bristol BS8 2PR, UK.

STUDY DESIGN

Most analytical studies use a case-control approach. This is because Parkinson's disease is relatively rare. Any prospective study needs to have a large sample size to generate sufficient cases for analysis. The combined alumni cohorts of Harvard and Pennsylvania colleges consisted of 50000 people and only generated 160 cases. ${ }^{6}$ Older cohorts will be more efficient in terms of statistical power. Casecontrol studies, although far more practical, are more prone to bias. Particularly problematic is the recruitment of control subjects and the measurement of putative exposures. Associations must be treated with some caution and if possible verified using either historical data or a cohort design.

\section{CASE DEFINITION}

The case definition for Parkinson's disease is based on clinical criteria. Only two thirds of potential cases of Parkinson's disease recruited directly from primary care may truly have the disease as validated by postmortem diagnosis.? Prevalence studies from various countries have shown that potential cases will include patients with benign essential tremor, dementia, and cerebrovascular disease. ${ }^{8-10}$ In Aberdeen, $15 \%$ of potential cases were excluded after specialist examination. ${ }^{8} \mathrm{~A}$ clinical diagnosis by a neurologist or geriatrician is also limited. The United Kingdom Parkinson's Disease Society Brain Bank data have shown that the predictive value of an expert diagnosis is only around $75 \% .^{11}$ The use of stricter clinical criteria can improve the predictive value but this is at the cost of excluding more genuine cases and is therefore only really of value for therapeutic trials rather than epidemiological studies. ${ }^{12}$ The use of complex investigations, such as PET, is not suitable for large epidemiological studies. The result of including other disorders as well as true cases of Parkinson's disease in a study will depend on the relation between these diseases and the exposures of interest. If this is no different to that found for Parkinson's disease, the results will not be biased. It is more reasonable to assume that they do not share the same aetiological factors. In this case, misclassification will bias the results towards the null; it will be harder to show a relation between exposure and disease, even if it truly exists.
MEASUREMENT OF EXPOSURE

The measurement of exposure is also problematic. It is unclear as to when in the lifecourse an 
Figure 1 Nigral cell loss: possible periods during the lifecourse for the role of an environmental factor. Cell loss is shown at a constant rate for simplicity; see text for details. (Modified from Langston ${ }^{17}$.)

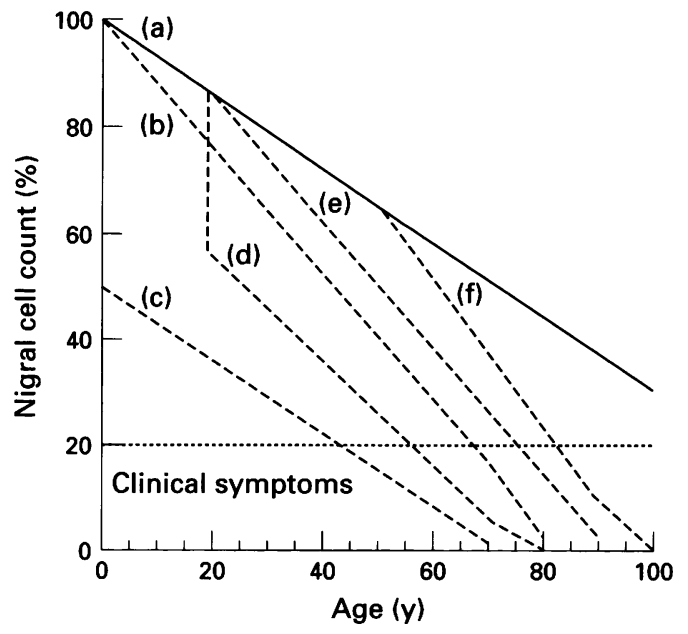

exposure may be important (fig 1). Clinical symptoms are thought to start once cell loss has reached a threshold level of $70 \%$ to $80 \%$. Normal age-related cell loss (a) is thought not to result in disease unless current life expectancy is prolonged. A genetic model might propose that cell loss from birth occurred in some people at a faster than normal rate (b) due to "aging genes".13 Intrauterine events, such as infection or placental abnormalities, ${ }^{14} 15$ might result in a person being born with a depleted cell count and normal age related loss (c) would ensure that disease would appear in later life. This developmental model has been proposed to explain the discordance rate seen for monozygotic twins. ${ }^{15}$ Environmental factors could act through an acute mechanism-for example, a head injury (d) destroying a finite number of cells-followed by normal age related loss (two stage hypothesis). ${ }^{16}$ Alternatively a low level chronic exposure (e)-for example, a diet relatively deficient in antioxidants - may simply act by slightly accelerating the rate of cell death. Finally an acute event-for example, exposure to a toxic chemical-may act by triggering cell death which results in a cascade of events and accelerated cell death (f). This final model would suggest that a long latency period may not be essential for disease aetiology and would focus attention on later life. Most people believe that a long latency period for Parkinson's disease is most likely. ${ }^{17-19}$ However, pathological data challenge the hypothesis that age related cell loss on top of an external insult is important. ${ }^{20}$ It is also possible that causation is heterogenous and that any one of the various models might operate in different persons to produce cell loss and this would be clinically indistinguishable.

Recently, the temporal profile of neurodegeneration in Parkinson's disease has been compared by various mathematical models to distinguish between different patterns of cell loss. ${ }^{21}$ Several important, and possibly questionable, assumptions had to be made to enable the calculations to be performed. The empirical data seemed to be compatible with both an "event" that kills some neurons and reduces the life expectancy of others and a "process" which continuously kills healthy neurons at a constant rate. It did, however, exclude a process which resulted in either an accelerating or decelerating cell death.

Most exposures are measured by subjective recall. This has two problems: low impact exposure, such as past diet, is likely to be poorly recalled by both cases and controls (non-differential misclassification). This will dilute any true relation and lead to erroneously concluding that there is no relation. High impact exposures might be differentially recalled by cases and not controls, particularly if there is pre-existing knowledge of a possible link between the exposure and disease. For example, a previous head injury might be more salient in the minds of patients than in controls, as they may link the trauma with their neurological disease (recall bias).

\section{GEOGRAPHICAL PATTERNS}

International comparisons have in the past relied on mortality rates adjusted for demographic differences between countries. Early findings showed a sevenfold to eightfold variation in mortality rates ${ }^{22} 23$ suggesting an important role for environmental factors as well as possible genetic differences. Mortality rates are susceptible to variations in diagnosis, survival, and certification practice, which could produce large artefactual differences. This is best illustrated by the fivefold mortality differences between Scotland and Japan. ${ }^{22}$ However, there is little difference in the prevalence rates for patients between 60 and 69 years of age, when underascertainment should be less problematic (Scotland 254/100 0008; Japan 245/100 000). ${ }^{9}$ More complex approaches differentiate between "multisource" prevalence studies, which rely on the complete identification of patients with a pre-existing diagnosis, and "population based" surveys which screen a total defined population identifying both preexisting and new cases. ${ }^{24}$ The population based survey method is particularly important for developing countries because of limited medical services or for communities in which there may be differential access to health care. For example, differential access to health care for ethnic minorities is well recognised in the United States ${ }^{25}$ and in the Copiah county study, more previously undiagnosed black patients $(58 \%)$ than white patients $(32 \%)$ were found. ${ }^{26}$ The population based survey method also enables more valid comparisons between studies as ascertainment is more standardised than conventional multisource studies. Unfortunately, as the prevalence rates are usually based on relatively few cases they are less robust, with wide confidence intervals.

Age adjusted prevalence rates suggest that a threefold difference may exist, with Libya $(57 / 100000)$ at one end and Iceland (182/ $100000)$ at the other. ${ }^{24}$ Prevalence rates are also susceptible to differences in diagnosis and survival. Artefactual differences can be reduced by limiting the comparison to European countries with good healthcare systems, using incidence rates as these are independent of differences in survival, and comparing rates for subjects under 70 years, in whom underascer- 
Table 1 Age specific incidence rates per 100000 for Parkinson's disease from selected European studies

\begin{tabular}{|c|c|c|c|c|c|c|c|c|}
\hline \multirow[b]{2}{*}{ Country (period) } & \multicolumn{7}{|c|}{ Rates per age group } & \multirow{2}{*}{$\begin{array}{l}\text { Relative rates * } \\
(95 \% \text { CIs })\end{array}$} \\
\hline & $30-39$ & $40-49$ & $50-59$ & $60-69$ & $70-79$ & $80-89$ & $50-69$ & \\
\hline $\begin{array}{l}\text { Iceland } \\
(1954-63)\end{array}$ & $1 \cdot 4$ & $5 \cdot 6$ & $32 \cdot 9$ & $97 \cdot 2$ & $136 \cdot 2$ & $69 \cdot 2$ & $61 \cdot 3$ & $2 \cdot 75(2 \cdot 31-3 \cdot 27)$ \\
\hline $\begin{array}{l}\text { Southwest Finland } \\
(1968-70)\end{array}$ & $0 \cdot 7$ & $2 \cdot 6$ & $19 \cdot 8$ & $62 \cdot 3$ & $92 \cdot 6$ & $47 \cdot 9$ & $40 \cdot 1$ & $1.80(1.46-2.21)$ \\
\hline $\begin{array}{l}\text { Ferrara, Italy } \\
(1967-87)\end{array}$ & 0.7 & $7 \cdot 2$ & $25 \cdot 1$ & $49 \cdot 6$ & $45 \cdot 8$ & $1 \cdot 1$ & $35 \cdot 9$ & $1.61(1.40-1.86)$ \\
\hline $\begin{array}{l}\text { Aarhus, Denmark } \\
(1967-70)\end{array}$ & 0.0 & $1 \cdot 0$ & $15 \cdot 8$ & $39 \cdot 8$ & $58 \cdot 5$ & $28 \cdot 1$ & $26 \cdot 8$ & $1.20(0.90-1.60)$ \\
\hline $\begin{array}{l}\text { Netherlands } \\
(1983-5)\end{array}$ & $0 \cdot 0$ & $0 \cdot 0$ & $14 \cdot 5$ & $25 \cdot 7$ & $79 \cdot 3$ & $117 \cdot 2$ & $19 \cdot 5$ & $0.88(0.54-1.42)$ \\
\hline Sardinia, Italy & $1 \cdot 3$ & $7 \cdot 1$ & $26 \cdot 4$ & $18 \cdot 0$ & $4 \cdot 3$ & 0.0 & $22 \cdot 3$ & $1 \cdot 00$ \\
\hline
\end{tabular}

${ }^{\star}$ Relative rate for 50-69 years compared with Sardinia, Italy.

Data taken from de Pedro-Cuesta. ${ }^{27}$

tainment should not be important. ${ }^{27}$ These results (table 1) suggest threefold variations, but this is reduced to less than twofold ( $80 \%)$ if Iceland is excluded. No obvious geographical pattern emerges, and the rates for Denmark and Holland are more similar to Sardinia than rates from Ferrara, Italy. Community door to door studies suggest that prevalence rates (fig 2) are fairly similar between both developed and some developing countries except for China and west Africa. A recent pilot study from Taiwan (not shown in fig 2) found much higher rates than in China, even though it was carried out in a rural area. ${ }^{28}$ This suggests that black persons in America and Chinese in Taiwan have higher rates of disease than their counterparts in west Africa or China. Environmental factors may thus be more important than racial factors in explaining these variations. ${ }^{26}$

A recent report on the prevalence of Lewy bodies in brains from Nigerians examined at postmortem has shown similar rates to those in western populations. ${ }^{29}$ Assuming that incidental Lewy bodies reflect preclinical disease, this finding supports the notion that the propensity to develop Parkinson's disease is universal. It also supports the role of environmental factor(s), as it is still necessary to explain why some Afro-Americans go on to develop clinical disease whereas their African counterparts remain asymptomatic. ${ }^{30}$

COMMENT

It is clear that Parkinson's disease is found throughout the world, but is less common in some countries such as China and Africa. This may reflect racial differences in genetic susceptibility or the absence of specific environmental factors related to industrialisation. In China there is some evidence to support the role of industrialisation as residing in a village residence was seen to be protective. ${ }^{31}$ There is a need for further migrant studies to elucidate the role of environmental factors. ${ }^{32}$ Across Europe there is relatively little variation, and what there is may be explained by methodological differences. Current standardised population based prevalence surveys will determine whether these differences are artefactual. The surprisingly high rates seen in Iceland may be idiosyncratic or reflect a higher degree of ascertainment when surveying a small population. ${ }^{33}$ Analysis of more recent drug utilisation data for Iceland supports this finding. ${ }^{34}$ Further work should confirm this observation and explore possible reasons, be they genetic or environmental.

\section{Temporal patterns}

MORTALITY RATES

Descriptions of what might have been Parkinson's disease existed well before the 19th century. The ancient ayurvedic literature (4500-1000 BC) of India describes an illness "kampavata" consisting of tremor and akinesia. ${ }^{35}$ Analysis of temporal trends have mostly relied on long term patterns in mortality rates. Studies from several different countries have all shown similar patterns of mortality over time: the United States, ${ }^{36-38}$ United Kingdom, ${ }^{39-42}$
Figure 2 Age adjusted prevalence rates 100000 from door to door surveys. * Indicates crude prevalence and not age adjusted. The study by Tison et al ${ }^{66}$ from Gironde, France is not shown. (Data amended from Zhang and Roman ${ }^{24}$.)

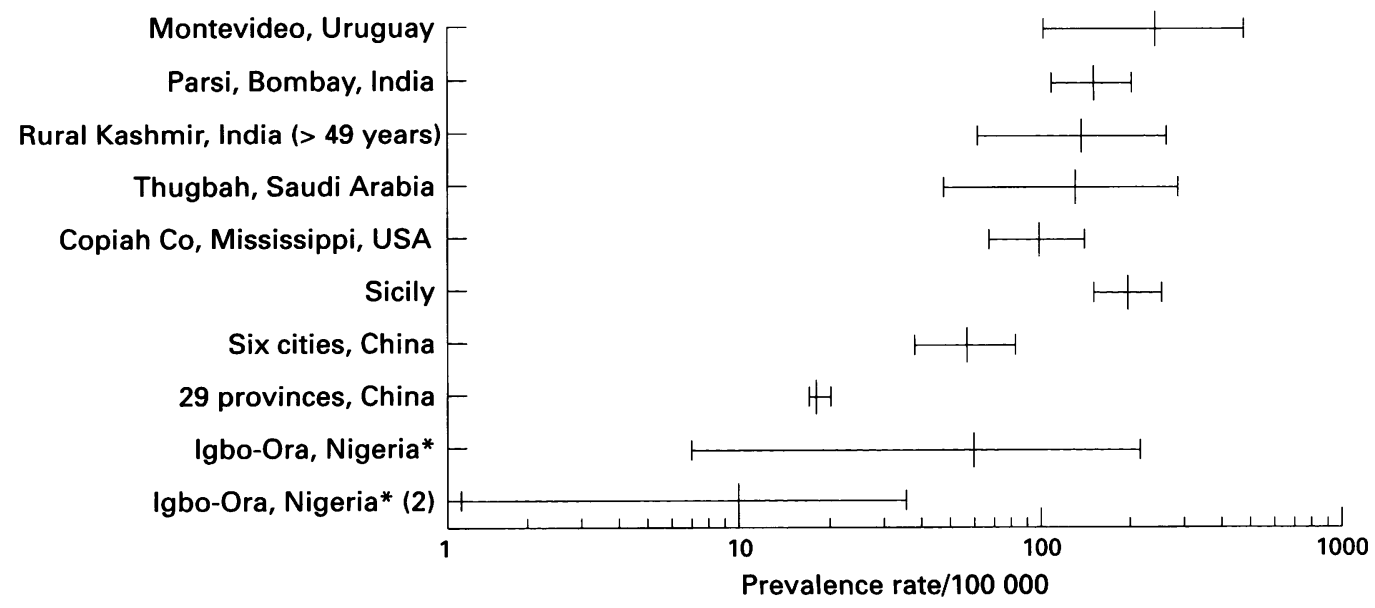


Ireland, ${ }^{43}$ Italy, ${ }^{44}$ Norway, ${ }^{45}$ Denmark, ${ }^{36}$ and Japan. ${ }^{46}$ Mortality rates for both men and women have shown increases for older age groups ( $>75$ years), and a decline for younger age groups ( $<65$ years). These patterns are remarkably consistent and predate the widespread introduction of levodopa in the 1970s. There are several possible explanations for these patterns. (1) Awareness, diagnosis, and certification of Parkinson's disease, particularly in elderly patients, may have increased over time. This might explain some of the increase seen for older patients but is unlikely to explain the rise seen before the 1970 s. It is unlikely to explain the differential increase in mortality seen for men compared with women..$^{38}$ White men over 80 showed a $100 \%$ greater increase than women when comparing mortality changes between 1962 and 1984. This is unlikely to reflect diagnosis or treatment and could reflect occupational risk factors. ${ }^{38}$ This pattern has also been seen in data from England and Wales (unpublished personal observation). (2) Levodopa treatment may have increased survival resulting in a shift of the age specific mortality curve to the right by about five years. ${ }^{36}$ There is some evidence to suggest that the initial introduction of levodopa treatment may have delayed death. ${ }^{47}$ However, more recent survival cohorts ${ }^{48} 49$ suggest that mortality from Parkinson's disease compared with that of the general population has not altered to a large degree from the prelevodopa days. ${ }^{50}$ There has been a secular increase in life expectancy for the whole population, so that a patient with Parkinson's disease today would expect to live longer like anyone else in the population. (3) There may have been a genuine change in the incidence of disease: (a) The incidence of disease in elderly people may have increased because of a reduction in heart disease and stroke mortality and hence a decline in competing causes of death..$^{51}$ If the risk of Parkinson's disease was also associated with heart disease or stroke, a reduction in deaths from heart disease would selectively increase the pool of potential subjects who could develop Parkinson's disease. Only one study has shown such an association ${ }^{49}$ and this has not been replicated..$^{52}$ If these diseases are independent of each other, then whereas a reduction of heart disease will increase the absolute number of cases of Parkinson's disease, it will not alter the age specific rates. (b) There has been a decrease in the incidence of disease in young age groups due to a decrease in environmental exposures. ${ }^{37}(c)$ The divergence of age specific mortality rates reflects a cohort effect due to a self limiting exposure, such as the encephalitis lethargica epidemic. ${ }^{53} 54$ Such a hypothesis would predict an increase in mortality as "exposed" cohorts aged but a decline in the mortality of younger age groups who would have been born after the exposure. As these later unexposed cohorts reached old age there would be a subsequent reduction in mortality for all ages. There have been several attempts to examine the cohort hypothesis using mortality data. ${ }^{404143}$ Plotting mortality rates by birth cohort suggests excess mortality for cohorts born between 1875 and 1895 . Standardised mortality ratios for those aged 30-50 in 1920 in England and Wales were raised compared with those born earlier or later. ${ }^{40}$ More recent multivariate modelling methods have been developed to disentangle age, period, and cohort effects. ${ }^{55}$ Initial analyses using these methods support these findings for both England and Wales and United States data (C Martyn, personal communication). Despite these complex methods, there is still an essential problem that cohorts born after the epidemic from the mid-1930s are still relatively young ( $<65$ years) and have not reached the age when mortality rates have been shown to be increasing. The cohort hypothesis is also unlikely to explain the differential mortality increase seen for men (see above) as there was little difference in encephalitis lethargica mortality rates for men and women. ${ }^{56}$

\section{INCIDENCE RATES}

Incidence rates are far superior to mortality rates, but are still potentially biased by temporal trends in consulting behaviour and doctor diagnosis. Data from Rochester, Minnesota are unique in covering a long period (1935-79). ${ }^{57-59}$ The annual incidence rate has increased from $11 \cdot 4 / 100000$ in $1935-44$ to $18 \cdot 2 / 100000$ between 1967 and 1979. The age adjusted rates have remained fairly constant over the past 30 years. ${ }^{24}$ Age adjusted rates can mask heterogeneity in age specific patterns as rates in older age groups could increase whereas those in younger groups decreased leaving the adjusted rate unchanged. The use of different age groupings in the two previous publications ${ }^{585}$ makes it impossible to compare the age specific rates over this entire period. Comparing 1945-54 with $1955-66$, it does seem that the rate for patients aged between 40-69 has decreased whereas that for those over 70 years has increased..$^{60}$

\section{COMMENT}

Temporal data are limited and difficult to interpret. Mortality rates among elderly people have increased substantially but the interpretation of this finding is controversial. The most reliable data to answer this question come from Rochester, Minnesota. A reanalysis of the Rochester data including more recent data between 1980 and 1995 is essential to help us discriminate between various competing hypotheses.

\section{Individual risk factors}

SOCIODEMOGRAPHIC FACTORS: AGE, SEX, AND SOCIAL CLASS

The risk of developing Parkinson's disease increases as a person gets older. But, it is unclear whether the increase in risk is continuous or eventually declines for the oldest age groups. The first pattern would favour the notion of "aging-related" degeneration as has been argued for Alzheimer's dementia. ${ }^{61}$ Multisource prevalence studies suggest that prevalence rates generally fall for the oldest age groups (table 1). It is likely that older subjects 
are less likely to present for medical attention, are more difficult to diagnose, and even when under residential care may be missed. ${ }^{62}$ Population based studies consistently show that prevalence rates increase continuously in an exponential fashion. ${ }^{263-66}$ Because broad age groups are used to calculate the age specific rates, it is possible that these studies could mask a flattening of the age curve. However, the study from Gironde, France calculated rates for five year age groups between 65 and older than 90 years and also found an exponential rise. ${ }^{66}$

Most studies support an excess of male to female cases. The average ratio of male to female standardised rates is 1.35 from prevalence studies and 1.31 from incidence studies, but the range is wide. ${ }^{24}$ This excess is seen for both multisource and population based studies. Hospital based studies may be misleading, as there is evidence that the survival of women recruited from hospitals is worse than men and hence will bias the results in favour of increasing the prevalence of men compared with women. ${ }^{49}$

Adult social class is a variable often measured in epidemiological studies ${ }^{67}$ as it is so strongly related to many diseases, ${ }^{68}$ and is often used as a confounding variable when examining other exposures. American studies tend to use a classification based on years of education or income, whereas European studies are more likely to use an occupation based classification. ${ }^{69}$ As a variable it is non-specific, and acts as a proxy marker for many other exposures such as smoking, diet, obesity, occupational exposures, sanitary conditions, overcrowding, risk of infection, income, etc. Many potential risk factors are distributed in a graded fashion by socioeconomic class. Showing a gradient in disease by socioeconomic class is often not very helpful as it fails to indicate which one of the many potential exposures is of importance. However, the lack of a gradient is of relevance as it challenges conventional hypotheses. For example, if it is speculated that Parkinson's disease is the result of a chemical exposure, it is likely that such an exposure would be greater for manual rather than non-manual jobs, unless the chemical is commonly found in the domestic home environment. Similarly, risk of infection will be associated with crowding, sanitary conditions, and hence socioeconomic class.

Mortality data from the United Kingdom show no social class gradient for deaths between $20-64$ years. For older ages there is a gradient with higher ratios in social class I and II than IV and V. ${ }^{70}$ However, proportional mortality ratios are influenced by the strong social class gradient for other more common causes of death, which would artefactually increase the proportion of mortality from Parkinson's disease in higher social classes. ${ }^{71}$ More reliable data can be obtained from case-control studies. Unfortunately, few studies have either examined or reported the results for adult social class and none have reported parental social class, which would reflect childhood living conditions.
Almost every study has failed to show any relation with years of education. ${ }^{72-75}$ One study which did show that cases were better educated $^{76}$ failed to adjust for age or sex, two important confounders as controls were both older and were more likely to be women. Similarly, a study of early onset Parkinson's disease showed an initial twofold increased risk associated with having completed high school graduation, but this was almost completely attenuated after adjustment for smoking habit and other variables. ${ }^{77} \mathrm{~A}$ case-control study with discordant twin pairs suggested that cases were less likely to be manual workers but this was not significant (odds ratio $0.50 ; 95 \%$ confidence interval (95\% CI) $0 \cdot 10-2 \cdot 23) .^{78}$ Only one prospective study has reported social class and again found no relation. ${ }^{79}$ Farming has been examined as a specific occupation with a possible raised risk. Some ${ }^{758081}$ but not all studies $^{82} 83$ have shown an increased risk. This could relate to pesticide use or other exposures that are more common in rural areas (see later).

\section{COMMENT}

Parkinson's disease is more common among older subjects and men. Limited evidence suggests that risk increases continuously with age. Further evidence is required to test the "aging related" hypothesis by focusing on population surveys of elderly people. It is important to determine why men have an increased risk compared with women. This could be related to smoking behaviour or other toxic exposures. Most case-control studies match cases and controls by sex, and are unable to examine the odds ratio associated with sex before and after adjustment for other risk factors. A population based case-control study, which does not match subjects by sex, would be useful to clarify this issue. There seems to be little social class or educational gradient. If anything, the risk seems increased with higher socioeconomic class or more years of education. The lack of a gradient is surprising as exposures to toxic agents, infectious agents, etc are likely to differ by social class. Adult social class is moderately correlated with parental social class but over the past 60 years there has been upward social mobility. Exposures acting in childhood may be more relevant than adult factors and future studies need to examine childhood circumstances by collecting data on parental social class as well as other childhood variables.

\section{Specific exposures}

Many potential exposures have been cited as possible risk factors for Parkinson's disease. These can broadly be divided into three groups: toxic exposures, infectious exposures, and a heterogenous group of miscellaneous exposures. Table 2 lists some of the studies that have investigated these exposures. Cohort studies provide the most robust observational data.

\section{TOXIC EXPOSURES}

The report that 1-methyl-4-phenyl-1,2,5,6tetrahydropyridine (MPTP) has neurotoxic 
Table 2 Relation between environmental risk factors and Parkinson's disease according to study design

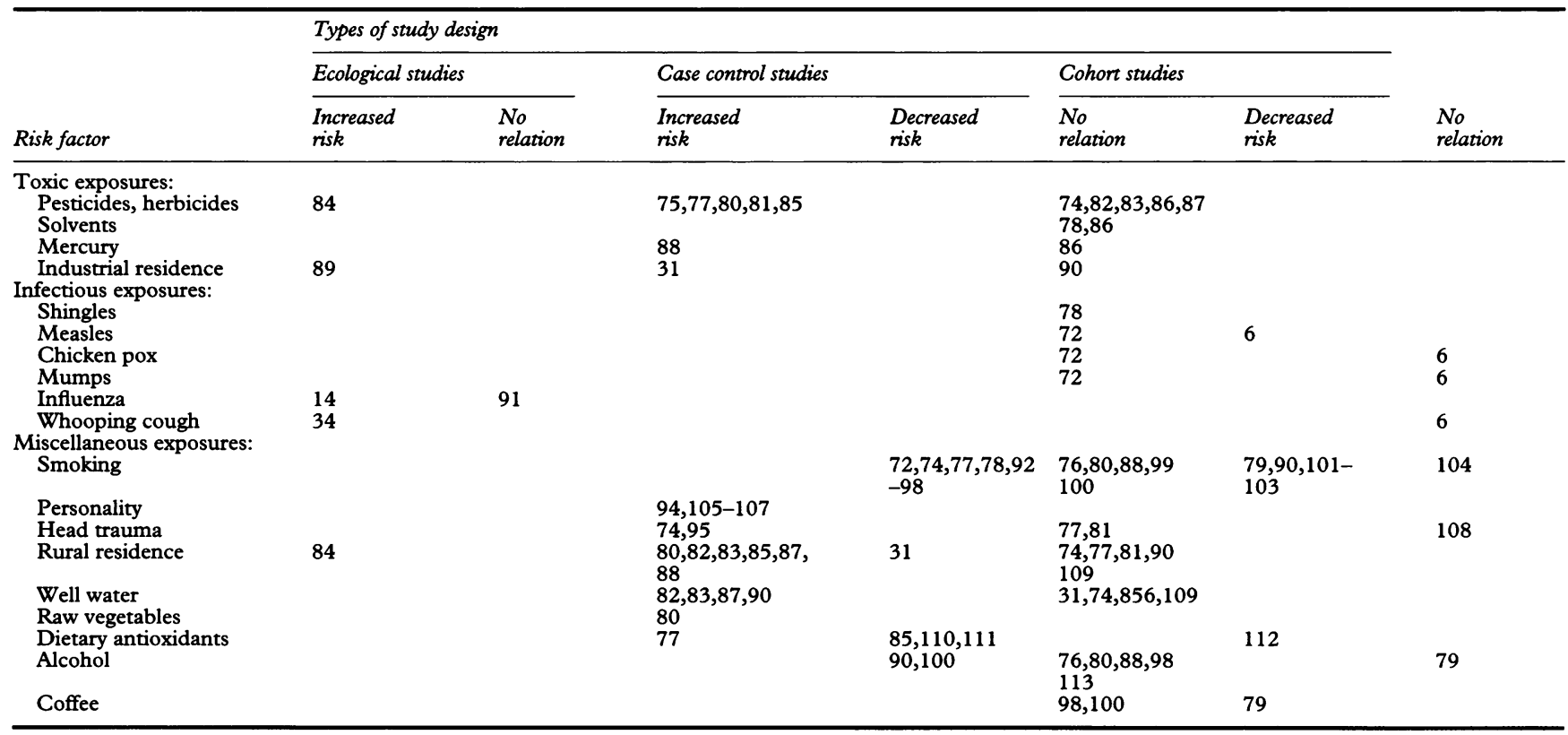

If a study has a non-significant result, it has been classified as showing no relation even if the results are in the same direction as other studies.

effects in humans ${ }^{114}$ has led to the hunt for a more commonly occurring environmental toxin. The validity of using the MPTP model to generate clues relating to idiopathic Parkinson's disease is generally thought to be reasonable. ${ }^{115}$ Paraquat is similar in structure to MPTP ${ }^{116}$ and therefore most attention has focused on herbicides and pesticides, although other toxic compounds, such as manganese and mercury, which are known to have neurological effects, have also been examined. An early ecological study from Canada showed a positive relation between a rural area with the greatest pesticide usage and both Parkinson's disease mortality and drug utilisation levels. ${ }^{84}$ Case-control studies can be divided into those that show an association ${ }^{75} 77808185$ and those that do not. ${ }^{7482} 838687$ Several possibilities exist to explain these discrepant results. Most of the studies that show an association, suggest a threefold increased risk associated with pesticide use. A weak study may have insufficient power to detect such a risk and would lead to a spurious negative finding (type II error). However, several of the negative studies were sufficiently large to have significantly detected such an increased risk..$^{83}$ For example, the Kansas study was sufficiently powerful to detect a twofold increased risk. ${ }^{83}$ Most of the studies have measured occupational pesticide exposures $^{75}{ }^{83}$ but some have included domestic exposure. ${ }^{74} 80$ Recall bias is unlikely to explain this association as there is no reason that it should operate in some but not all studies given the similarity of their populations. Empirical evidence suggests that differential recall for pesticides between cases and controls is not a serious consideration. ${ }^{17}$ Studies that show an increased risk with pesticides also tend to be the same studies with an increased risk for rural residence. This is to be expected as occupational pesticide use is likely to be more common in rural areas. An artefactual association between pesticides and Parkinson's disease could exist if "selection bias" resulted in an over-representation of rural cases compared with rural controls (see section on rural residence for detailed discussion). However, in some studies the association with pesticide use was present ${ }^{75}$ despite no association with rural residence $^{109}$ and vice versa. ${ }^{83}$ The study from Calgary, Canada ${ }^{75} 109$ is particularly impressive as its design should have minimised any selection bias and it also obtained detailed occupational histories. One possibility is that pesticides differ between studies and only some types show an association with Parkinson's disease. However, this explanation is unlikely as most of these studies cover a similar period and examine populations in North America.

Cross sectional data show an association between exposure to organophosphate pesticides and subtle differences in both cognitive processing and depression. ${ }^{118}$ Depression has been shown to be common in Parkinson's disease and may predate clinical symptoms. ${ }^{119} 120$ It is not clear whether these results have any relevance to the pathophysiology of Parkinson's disease. As this study was cross sectional, it is uncertain whether such subtle cognitive differences may not have existed before the exposure. Only limited data are available on occupational cohorts. The "Iowa $65+$ rural health study" showed that farmers, either still working or retired, were less likely to have Parkinson's disease compared with other rural controls. ${ }^{121}$ No information was provided, however, as regards their pesticide exposure and smoking habit was not taken into account.

The hypothesis that toxins are involved has been given much more credence by the recent discovery that patients with Parkinson's disease have relatively less effective detoxification systems. ${ }^{122-126}$ This enhances the plausibility of the "ecogenetic" hypothesis that Parkinson's disease may result from the combination of an inherited susceptibility and an environmental toxin. If susceptibility is relatively rare-for example, the proportion of the general population with poor metaboliser status for debriso- 
quine is thought to be between $5 \%$ and $10 \%$ the exposure may be common as most exposed subjects will not experience any adverse results. From an epidemiological perspective, a common exposure experienced by $80 \%$ or more of the general population will be much harder to detect and require far larger sample sizes. Studies will either need to be restricted to subjects with the susceptibility genes or must be able to test for interactions between genetic and exposure state.

The public health importance of pesticide use as a cause of Parkinson's disease is limited. Assuming a causal relation, the population attributable risk-that is, the percentage of all cases of Parkinson's disease that might be related to occupational pesticide use-is only around $10 \%$, although this could vary between $2 \%$ and $25 \% \quad(95 \%$ CI $){ }^{75}$ This estimate excludes non-occupational exposure, which is far more common although less intense. If some subjects are particularly susceptible to even low level exposure, then pesticides could pose a far more serious public health risk.

\section{INFECTIOUS EXPOSURES}

The notion that Parkinson's disease could be related to an infectious agent is far older and has existed since the recognition of postencephalitic parkinsonism. Other neurological diseases, such as subacute sclerosing panencephalitis, also provide an analogous model of disease related to latent infection. Whereas a toxic hypothesis has risen in popularity, an infectious hypothesis has declined and work examining infections is generally older. ${ }^{6} 1434727891$ Some authorities consider that "the disease is not of viral origin . . ."127 and hence there is no further need to test this hypothesis. Indeed, the inconsistent seroepidemiological results ${ }^{128} 129$ and failure to detect specific viral particles, inclusions, or antigens in brain necropsy material $^{130}$ suggest that pursuit of this hypothesis may be fruitless. However, several intriguing observations remain which require an answer. Serological analyses suggest, if anything, that serum antibody titres in cases of Parkinson's disease are often no different or lower than for controls. For example, titres for measles, rubella, herpes simplex 1 , herpes simplex 2, mumps, and cytomegalovirus were all lower for patients, with the first three being statistically significant. ${ }^{128}$ Although serological data are objective, they cannot identify the age at infection, which might be a more important predictor than infection itself. ${ }^{34} 131$ Studies that have used subjective reporting of infections also show no significant differences between cases and controls, except for measles infection, which has been reported to be less frequent among college students who went on to to develop Parkinson's disease. ${ }^{6}$ However, pertussis, chicken pox, and mumps infection also seem to be less common, ${ }^{672}$ consistent with the serological results. It is unlikely that recall bias could explain this as these results were found in both retrospective and prospective studies. Simple misclassification would bias the results towards the null. A reduced frequency of childhood infections could be a chance phenome- non, but might relate to other factors, such as infection in very early life. One study suggested the possibility of "in utero" infection but this was based on ecological data ${ }^{14}$ and failed to be replicated. ${ }^{91}$ Alternatively, it may reflect variations in immune function or the possibility of confounding by another factor such as socioeconomic class or family size. The non-specificity of the results favours the role of a confounding factor, but this remains unresolved.

\section{MISCELLANEOUS EXPOSURES}

Smoking and personality

The inverse relation between smoking and Parkinson's disease has been seen consistent for both case-control and cohort studies. Dorn, in one of the earliest smoking cohort studies, ${ }^{101}$ was so surprised by the association that he sought and received confirmation from both Doll and Hill ${ }^{103}$ and Hammond. ${ }^{102}$ Some publications have failed to show a statistically significant association but in most studies the results have been in the same direction. The consistency of this finding in different populations and using different methods, makes it reasonable to exclude chance as an explanation for this association. Other possible explanations are (1) Bias-Subjects may biologically age at different rates due to genetic differences in the ability to repair cellular damage. Smoking may adversely affect DNA repair mechanisms and therefore smokers with less efficient mechanisms would be selectively eliminated (selective mortality). Older surviving cigarette smokers would have relatively more effective DNA repair mechanisms and would therefore be protected from developing either Parkinson's disease or Alzheimer's disease. ${ }^{13} 132$ This argument is flawed for two reasons. ${ }^{133}$ Monozygotic twin pairs, when both twins are alive, still show the inverse association with smoking. Casecontrol studies using early onset cases show similar findings, even though selective mortality is unlikely to be of any importance for populations at this young age. (2) Causality-There are several biologically plausible reasons why smoking may protect or retard the development of Parkinson's disease. Hydrazine found in tobacco smoke protects mice from damage to nigrostriatal cells from MPTP. ${ }^{134}$ Carbon monoxide or other factors in cigarette smoke may scavenge free radicals. ${ }^{135}$ Smoking may have an effect on mitochondrial activity and oxidative damage. ${ }^{136}$ Polyaromatic hydrocarbons in tobacco smoke may induce cytochrome $P-450$ enzymes and lead to increased metabolism of xenobiotics. ${ }^{137}$ If smoking did in fact alter the rate of nigral cell death it could be predicted that smokers who developed Parkinson's disease would both be older than non-smokers and would have a slower rate of disease progression. Both of these predictions are refuted by empirical evidence. ${ }^{98-100} 138$ (3) Reverse causalityParkinson's disease makes people give up smoking as a secondary phenomenon. But the inverse association is still found if smoking habits are examined for a period before onset of clinical disease. ${ }^{7793}$ It is possible, however, 
that subtle changes in personality occur well before overt clinical disease as part of a more insidious onset. Such changes might effect smoking behaviour. Personality may therefore either act as a proxy marker of disease, or is a confounding variable unrelated to the disease process. (4) Confounding - There are premorbid personality differences associated with both the likelihood of becoming a smoker and continuing to smoke and other exposures/genes that are directly related to the risk of developing Parkinson's disease. Smokers seem to differ in personality traits from non-smokers and are more likely to be extrovert or exhibit type A behaviour. ${ }^{139}$ Non-smokers have higher levels of shyness and defensiveness. ${ }^{140}$ Similar personality differences may also determine alcohol consumption. Most studies show that patients with Parkinson's disease either are no different or have reduced alcohol consumption. ${ }^{90100}$ Patients with Parkinson's disease are reported to show personality changes, such as introvertism, that would make them less likely to be smokers. ${ }^{94}{ }^{105-107}$ We do not know, however, to what degree personality, such as being the more dominant twin, ${ }^{107}$ could influence other risk factors, such as migration from rural to urban areas or reducing the risk of exposure to pesticides. Alternatively certain genes may influence both the tendency to smoke and the risk of developing Parkinson's disease. This argument has been suggested to explain the similar association found with Alzheimer's disease. ${ }^{141}$

\section{Head trauma}

Some studies have noted an excess risk of head trauma among patients with Parkinson's disease than among controls. ${ }^{74} 95142$ This association is usually doubted because of the likelihood that it reflects recall bias. One method to reduce this possible bias is to only measure severe head injuries, such as those resulting in loss of consciousness. Even though such events should be recalled equally well by both cases and controls, patients with Parkinson's disease still show an increased risk. ${ }^{74}$ Another strategy to control for recall bias is to ask patients about their own "lay beliefs" as to what caused their disease. ${ }^{143}$ Patients who report trauma as a possible cause can then be removed from the analysis to determine the degree of potential bias, although this might underestimate the true risk. ${ }^{144}$ Only one study has examined a cohort of subjects with recorded head injuries and followed up their risk of Parkinson's disease. This study failed to find any increased risk but had a $30 \%$ probability of not detecting a twofold relative risk even if one existed. ${ }^{108}$ Susceptibility to trauma, rather than severity itself may be more important. If head injury triggers a cascade of biological events that lead to cell death in only a few susceptible people, then it may be more difficult to detect an increased risk in a head injury cohort than in a case-control study.

\section{Rural residence}

It is paradoxical that industrialisation has been proposed to explain the differences in geo- graphical prevalence rates between countries, yet within countries residing in a rural area has been noted to increase risk. ${ }^{77} 808283858788$ One of the first reports of such an association came from a Canadian series of 21 patients whose disease started under 41 years of age. ${ }^{145}$ This series noted an excess of rural patients who had drunk well water. Rural residence, like social class, is a rather non-specific variable as it could simply be a proxy marker for various other exposures, such as well water consumption, farming, pesticide exposure, diet, contact with farm animals, or age at infection. Any genetic susceptibility to develop Parkinson's disease may also differ between urban and rural populations, as isolated rural populations might have a greater degree of inbreeding.

Some studies have suggested that rural exposure in early life is more important, ${ }^{82}$ whereas others suggest that it is the total number of years. ${ }^{80}$ This finding is not consistent, with some studies showing a decreased risk ${ }^{31}$ or no significant risk. ${ }^{74} 778190109$ Demographic variables, such as rural residence, are particularly sensitive to the method of recruiting controls ${ }^{146}$ and the possibility of selection bias. Most studies recruit patients from neurology or movement disorder clinics based in urban centres. These specialist centres will often have a wide catchment area and see patients from both urban and rural areas. It is likely that elderly rural patients might be managed locally and not get referred on because of transport and access difficulties. ${ }^{147}$ This is not likely for atypical, severe, and young patients and specialist clinics will have an overrepresentation of these. ${ }^{148}$ Studies showing an increased risk (except one) selected controls from the hospital which recruited the cases. Controls were usually subjects with more common medical conditions such as heart or respiratory disease and would therefore be more likely to include local urban residents. Such a bias would artefactually increase the proportion of patients with Parkinson's disease from rural areas. The only exception ${ }^{85}$ used spouses as controls. It is unclear whether spouses might be more or less likely to come from the same area as the patient and this would depend on the level of migration and mixing of urban and rural residents. Studies which failed to show any increased risk used various methods: "buddy" controls, ${ }^{74}$ neurological clinic controls, ${ }^{90}$ stratified sampling, ${ }^{81}$ rheumatoid arthritis controls, ${ }^{77}$ and population based control selection. ${ }^{109}$ The use of buddy controls is not to be recommend as it may well result in overmatching. ${ }^{149}$ Selecting patients from a specialist clinic may diminish selection bias but is also problematic especially if a single disease entity is chosen. Only the population based study ensured non-biased ascertainment of both cases and controls ${ }^{109}$ and this study failed to show an association. In fact, rural residence in this study may have been associated with a decreased risk for those subjects not exposed to pesticides. As this study showed an increased risk for occupational pesticide use ${ }^{75}$ and this would be more common in rural areas, the risk for rural subjects not exposed to pesticides must have been reduced 
so that the overall rural risk was not raised. It is interesting to note that the incidence study from Ferrara, Italy did observe a greater risk of Parkinson's disease in rural areas, but this was restricted to patients under 50 years and was not seen among housewives. ${ }^{150}$

\section{Well water}

Well water, like rural residence, has also been seen to be associated with Parkinson's disease. This is not surprising as the two exposures are closely correlated. Hence studies that show a relation between rural residence also tend to show a relation with well water and vice versa. The strong correlation between these two variables is evident in the Kansas case-control study. Well water had a significantly raised odds ratio of 1.7 with Parkinson's disease, but after adjusting for rural residence this was attenuated to $1 \cdot 1 .{ }^{83}$ One study specifically used factor analysis in an attempt to overcome the problems of excessive collinearity. ${ }^{81}$ This is only a partial solution and does not overcome the problems of determining "independent" effects when measurement error is taken into account. ${ }^{151}$ Designing studies that specifically break the confounding between two closely correlated exposures is better than using complex statistical methods, but is not always possible in reality.

Well water could act as a carrier of a potential toxin or as a vector for an infective agent. No relation has been noted, however, in either pesticides or heavy metal composition of water supply sampled for early onset cases and controls. ${ }^{152}$ Other possible factors still need to be considered, such as the role of sulphur containing compounds. Patients with Parkinson's disease have reduced S-oxidation capacity and sulphate conjugation. ${ }^{123}$ Alternatively, well water, like rural residence, may again be simply a proxy marker for another exposure which is more common in rural environments.

\section{Dietary factors}

Diet could play a part in the aetiology of Parkinson's disease. The rare disease of amyotrophic lateral sclerosis/parkinsonism-dementia, seen on the Islands of Guam and Rota, is thought to be due to a dietary toxin from the cycad plant, ${ }^{153}$ which is not found in western diets. Diet is complex and it is difficult to quantify exposure. ${ }^{154}$ Usually all subjects are exposed to the hypothesised causal factors and thus continuous variables need to be measured, often with a limited range of variation. Retrospective data are especially prone to inaccuracy and recall bias. ${ }^{154}$ Recall of past diet in each case is seen to be strongly influenced by current dietary intake. ${ }^{155}$ This influence may be especially important in the context of case-control studies, in which the possibility exists that cases but not controls may alter their diets subsequent to the diagnosis of their disease. Several studies have found a relation between specific food stuffs and Parkinson's disease. These results are, however, still tentative. For example, one study showed that a "protective" effect with peanut consumption was seen only in females, and salad with dressing only in males. ${ }^{85}$ Nuts and seeds seemed to be harmful in yet another study. ${ }^{77}$ The most impressive data come from a large prospective cohort study of 41836 women, who have been followed up for six years. In this study there was no association between vitamin $\mathrm{E}$ and Parkinson's disease but a significant protective effect was seen for both vitamin $\mathrm{C}$ and manganese consumption, whereas vitamin $\mathrm{A}$ was associated with an increased risk. ${ }^{112}$ The failure of the DATATOP trial to show any benefit with $\alpha$-tocopherol ${ }^{156}$ should not be interpreted as excluding the potential role of dietary antioxidants. Firstly, it is possible that the wrong intervention was chosen, and secondly, dietary factors may protect disease onset (induction) and yet have little effect on prognosis once disease is established (promotion). For example, stopping smoking after the diagnosis of lung cancer has little effect on survival. Given the possible role of antioxidants in the aetiology of Parkinson's disease, these results need confirmation using validated methods of dietary assessment such as seven-day weighed diaries and prospective follow up. In view of the long latency period, it will also be important to consider both adult and childhood diet.

\section{COMMENT}

Various studies have raised the possibility that several different environmental exposures might be related to Parkinson's disease. A toxic exposure is perhaps the most attractive suggestion as it would be consistent with both the evidence on oxidative damage as well as genetic variations in detoxification systems. Several studies suggest pesticides to be of importance, yet this finding is not consistent and is still relatively non-specific. It is important that we collect more data on this exposure and refine current methods of exposure measurement, by combining self reporting measures with biological variables. Prospective occupational cohort studies among those known to have high exposures will need to confirm these associations and identify whether any risk is linked to a specific agent or a broader class of exposures. Infectious exposures seem, if anything, to be less frequent in cases of Parkinson's disease. The interpretation of this finding is uncertain and further work is required to examine not only exposure, but also age at exposure. Self recall data will be problematic and other proxy markers, such as household size, measures of crowding, etc should also be examined. The inverse relation between smoking and Parkinson's disease remains enigmatic but deserves further attention, particularly in relation to premorbid personality differences. In the future, cohort studies with data on personality and behaviour of children will eventually have sufficient cases of Parkinson's disease to test these questions definitively. At the moment these cohorts are still relatively young and have too few patients with Parkinson's disease. Head trauma cannot be definitively excluded as a risk factor, despite a negative cohort study of subjects with past head injury. Larger cohorts with documented injury or occupational cohorts at high risk of head 
trauma should be examined. Laboratory work is also needed to examine the biological plausibility of minor trauma precipitating a chain of biochemical events that result in cell death. The association between rural residence, well water consumption, and Parkinson's disease initially seemed to be a consistent and potentially important clue. However, the absence of any association in a population based case-control study is a serious concern as prior results may have been influenced by selection bias. This finding needs confirmation by further suitable studies. Population based prevalence studies comparing stable urban and rural populations in the same country will definitively answer whether there is any excess risk associated with residence in a rural area. The role of dietary factors is still unclear as current evidence is weak. More complex methods of dietary measurement using prospective cohorts would establish whether these results are artefactual.

\section{Comorbidity}

The association between Parkinson's disease and other diseases can be a useful clue as to shared common aetiological factors, be they genetic or environmental.

Cardiovascular disease, hypertension, and diabetes Heart disease and stroke have been reported to be less common in male patients with Parkinson's disease ${ }^{72}$ or to be no different from the general population. ${ }^{157}$ Most studies which have reported causes of death for patients with Parkinson's disease have used proportional mortality ${ }^{50} 158159$ and have therefore potentially underestimated the relevance of heart disease compared with the general population. ${ }^{71}$ One cohort study has reported a twofold to threefold increased risk for both heart disease and stroke compared with normal controls. ${ }^{49}$ However, this has not been replicated. ${ }^{52}$ Hypertension has either been less common ${ }^{99} 157$ or no different from control groups. ${ }^{727980}$ This might relate to abnormalities in autonomic control mechanisms. No increased risk has been seen for diabetes ${ }^{79} 80160$ despite the experimental finding that fructose blocks MPTP toxicity in isolated hepatocytes. ${ }^{161}$

Malignancy

Several studies have shown that patients with Parkinson's disease experience about half the number of cancers than would be expected from general population rates. ${ }^{49} 159$ 162-164 When this is examined in more detail, this deficit is specifically related to smoking related cancers $^{49} 162$ and is simply explained by the larger proportion of never smokers in the Parkinson's disease population.

\section{COMMENT}

Patients with Parkinson's disease have a different comorbidity profile than normal controls. The risk of cancers is lower as smoking related malignancies are less common. This is simply explained by the lower prevalence rates of smoking. It is unclear whether the risk of cardiovascular disease is increased in patients with Parkinson's disease.

\section{Conclusions}

There is little doubt that Parkinson's disease and other neurodegenerative diseases will increase in importance over the next few decades as the population continues to age and many of the other important causes of morbidity continue to decline. ${ }^{165}$ Epidemiological research on Parkinson's disease has flourished over the past 10 years, but many findings are still tentative or inconsistent. Future descriptive studies should focus on populations with either anomalous high or low rates of Parkinson's disease. High quality temporal data is essential to determine whether incidence rates are heterogenous depending on age and sex. Better data on elderly cohorts will clarify whether incidence of Parkinson's disease increases exponentially with age. Specific exposures need to be tested more rigorously, either by using special "at risk" cohorts, or by improving measurement of exposure, such as prospective cohorts with reliable measures of dietary intake. Our growing understanding of both the basic pathology and the possible role of genetic factors suggests that certain subgroups of the population may be more susceptible to potential environmental factors. Epidemiologists will need to collaborate with laboratory based researchers to disentangle the relative importance of each risk factor and examine for potential interactions.

I thank the two anonymous referees for useful comments on the initial version of this paper. Much of my knowledge about the epidemiology of Parkinson's disease was acquired while funded by a Wellcome Trust fellowship in clinical epidemiology.

1 Parkinson J. An essay on the shaking palsy. London: Sherwood, Neely, and Jones, 1817:1-66

2 Koller WC, Wong GF, Lang A. Posttraumatic movemen disorders: a review. Mov Disord 1989;4:20-36.

3 Factor SA, Sanchez Ramos J, Weiner WJ. Trauma as an etiology of parkinsonism: a historical review of the concept. Mov Disord 1988;3:30-6.

4 Stern MB. Head trauma as a risk factor for Parkinson's disease. Mov Disord 1991;6:95-7.

5 Khoury MJ, Beaty TH, Cohen BH. Fundamentals of genetic epidemiology. New York: Oxford University Press, 1993: $3-383$

6 Sasco AJ, Paffenbarger RS. Measles infection and Parkinson's disease. Am $\mathcal{F}$ Epidemiol 1985;122:1017-31. Parkinson's disease. Am $\mathcal{F}$ Epidemiol $1985 ; 122: 1017-31$.
Ben-Shlomo Y, Sieradzan K. Idiopathic parkinson's disease: epidemiology, diagnosis and management. $\mathrm{Br} f \mathrm{Gen}$ Pract 1995;45:261-8.

8 Mutch WJ, Dingwall-Fordyce I, Downie AW, Paterson JG, Roy SK. Parkinson's disease in a Scottish city. BMF 1986;292:534-6.

9 Harada H, Nishikawa S, Takahashi K. Epidemiology of Parkinson's disease in a Japanese city. Arch Neurol 1983, 40:151-4.

10 Martilla RJ, Rinne UK. Epidemiology of Parkinson's disease in Finland. Acta Neurol Scand 1976;53:81-102.

11 Hughes AJ, Daniel SE, Kilford L, Lees AJ. Accuracy of clinical diagnosis of idiopathic Parkinson's disease: a clinico-pathological study of 100 cases. $f$ Neurol clinico-pathological study of 100

12 Hughes AJ, Ben-Shlomo Y, Daniel SE, Lees AJ. What features improve the accuracy of clinical diagnosis in Parkinson's disease: a clinicopathological study Neurology 1992;42:1142-6.

13 Riggs JE. Smoking and Alzheimer's disease: protective effect or differential survival bias? Lancet 1993;342: 793-4.

14 Mattock C, Marmot M, Stern G. Could Parkinson's disease follow intra-uterine influenza?: a speculative hypothesis. F Neurol Neurosurg Psychiatry 1988;51:753-6.

15 Eldridge $R$, Ince $S E$. The low concordance rate for Parkinson's disease in twins: a possible explanation. Neurology 1984;34:1354-6.

16 Calne DB, Langston JW. Aetiology of Parkinson's disease. Lancet 1983;2:1457-9.

17 Langston JW. Predicting Parkinson's disease. Neurology 1990;40:70-4.

18 Koller WC, Langston JW, Hubble JP, et al. Does a long preclinical period occur in Parkinson's disease? preclinical period occur

19 Koller WC. When does Parkinson's disease begin? Neurology 1992;42 (suppl 4):27-31. 
$20 \mathrm{Gibb}$ WR, Lees AJ. The progression of idiopathic Parkinson's disease is not explained by age-related changes. Clinical and pathological comparisons with post-encephalitic parkinsonian syndrome. Acta Neuropathol (Berl) 1987;73:195-201.

21 Schulzer M, Lee CS, Mak EK, Vingerhoets JG, Calne DB. A mathematical model of pathogenesis in idiopathic parkinsonism. Brain 1994;117:509-16.

22 Goldberg ID, Kurland LT. Mortality in 33 countries from diseases of the nervous system. World Neurology 1962; 3:444-63.

23 Williams GR. Morbidity and mortality with parkinsonism. $f$ Neurosurg 1966;24 (suppl):138-43.

24 Zhang $Z$, Roman GC. Worldwide occurence of Parkinson's disease: an updated review. Neuroepidemiology 1993;12:195-208.

25 Hayward RA, Shapiro MF, Freeman HE, Corey CR. Inequities in health services among insured Americans. $N$ Engl F Med 1988;318:1507-12.

26 Schoenberg BS, Anderson DW, Haerer AF. Prevalence of Parkinson's disease in the biracial population of Copiah County, Mississippi. Neurology 1985;35:841-5.

27 de Pedro-Cuesta J. Parkinson's disease diagnostic criteria, incidence and etiology: III Europarkinson Workshop. Madrid: Institute of Health, 1991.

28 Wang SJ, Fuh JL, Liu CY, et al. Parkinson's disease in Kin-Hu, Kinmen: a community survey by neurologists. Neuroepidemiology 1994;13:69-74.

29 Jendroska K, Olasode BJ, Daniel SE, et al. Incidental Lewy body disease in black Africans. Lancet 1994;344:882-3.

30 Ben-Shlomo Y, Wenning G. Incidental Lewy body disease. Lancet 1994;344:1503.

31 Tanner CM, Chen B, Wang W, et al. Environmental factors and Parkinson's disease: a case-control study in China. Neurology 1989;39:660-4.

32 Marmot MG, Adelstein AM, Bulusu L. Lessons from the study of immigrant mortality. Lancet 1984;i:1455-8.

33 Gudmundsson KR. A clinical survey of Parkinsonism in Iceland. Acta Neurol Scand 1967;43 (suppl 33):9-61.

34 de Pedro-Cuesta J, Petersen IJ, Stawiarz L, et al. High levodopa use in periodically time-clustered, Icelandic birth cohorts. A vestige of parkinsonism etiology? Acta Neurol
Scand 1995;91:79-88.

35 Manyam BV. Paralysis agitans and levodopa in "Ayurveda": ancient Indian medical treatise. Mov Disord 1990;5:47-8.

36 Kurtzke JF, Murphy FM. The changing patterns of death rates in parkinsonism. Neurology 1990;40:42-9.

37 Treves TA, de Pedro-Cuesta J. Parkinsonism mortality in the US, 1. Time and space distribution. Acta Neurol Scand 1991;84:389-97.

38 Lilienfeld DE, Chan E, Ehland J, et al. Two decades of increasing mortality from Parkinson's disease among the US elderly. Arch Neurol 1990;47:731-4.

39 Duvoisin RC, Schweitzer MD. Paralysis agitans mortality in England and Wales, 1855-1962. Br F Prev Soc Med 1966;20:27-33.

40 Marmot MG. Parkinson's disease and encephalitis: the cohort hypothesis re-examined. In: Rose FC, ed. Clinical neuroepidemiology. Kent: Pitman Medical, 1980; 391-401.

$41 \mathrm{Li} \mathrm{T}$, Swash M, Alberman E. Morbidity and mortality in motor neuron disease: comparison with multiple sclerosis and Parkinson's disease: age and sex specific rates and cohort analyses. $\mathcal{F}$ Neurol Neurosurg Psychiatry 1985;48. 320-7.

42 Clarke CE. Mortality from Parkinson's disease in England and Wales 1921-1989. I Neurol Neurosurg Psychiatry 1993;56:690-3

43 Ben-Shlomo Y, Finnan F, Allwright S, Davey Smith G. The epidemiology of Parkinson's disease in Ireland:
observations from routine data sources. Ir Med $\mathfrak{f}$ 1993;86:190-4.

44 Vanacore N, Bonifati V, Bellatreccia A, Edito F, Meco G. Mortality rates for Parkinson's disease and parkinsonism in Italy (1969-1987). Neuroepidemiology 1992;11:65-73.

45 Kurtzk JF, Flaten TP, Murphy FM. Death rates from Parkinson's disease in Norway reflect increased survival. Neurology 1991;41:1665-7.

46 Imaizumi $Y$, Kaneko $R$. Rising mortality from Parkinson's disease in Japan, 1950-1992. Acta Neurol Scand 1995 91:169-76.

47 Clarke CE. Does levodopa therapy delay death in Parkinson's disease? A review of the evidence. Mov Disord 1995;10:250-6.

48 Ebmeier KP, Calder SA, Crawford JR, Stewart L, Beeson JAO, Mutch WJ. Parkinson's disease in Aberdeen: survival after 3.5 years. Acta Neurol Scand 1990;81:294-9.

49 Ben-Shlomo Y, Marmot MG. Survival and cause of death in a cohort of patients with parkinsonism: possible clues to in a iology. F Neurol Neurosurg Psychiatry 1995;58:293-9.

50 Hoehn MM, Yahr MD. Parkinsonism: onset, progression and mortality. Neurology 1967;17:427-42.

51 Riggs JE, Schochet SS. Rising mortality due to Parkinson's disease and amyotrophic lateral sclerosis: a manifestation of the competitive nature of human mortality. $₹ \mathrm{Clin}$ of the competitive nature

52 Bennett DA, Beckett LA, Murray AM, et al. Prevalence of Parkinsonian signs and associated mortality in a community populat

53 Poskanzer DC, Schwab RS. Cohort analysis of Parkinson's syndrome. Evidence for a single etiology related to subclinical infection about 1920. F Chron Dis 1963;16: 961-73.
54 Brown EL, Knox EG. Epidemiological approach to Parkinson's disease. Lancet 1972;1:974-6.

55 Holford TR. Analysing the temporal effects of age, period and cohort. Statistical Methods in Medical Research 1992;1:317-37.

56 Ravenholt RT, Foege WH. 1918 Influenza, encephalitis lethargica, parkinsonism. Lancet 1982;ii:860-4.

57 Kurland LT, Hauser WA, Okazaki H, Nobrega FT. Epidemiologic studies of Parkinsonism with special reference to the cohort hypothesis. In: Proceedings of the third ymposium on Parkinsonism. Edinburgh: Livingstone, 1969:12-6.

58 Nobrega FT, Glattre E, Kurland LT, Okazaki H Comments on the epidemiology of parkinsonism including prevalence and incidence statistics for Rochester, Mreva 1953-1966. In: Barbeau A, Brunette JR, eds. Progress in Neurogenetics. Amsterdam: Excerpta Medica, 1969:474-85.

59 Raiput AH, Offord KP, Beard CM, Kurland LT. Epidemiology of parkinsonism: incidence, classification and mortality. Ann Neurol 1984;16:278-82.

60 de Pedro-Cuesta J, Stawiarz L. Parkinson's disease incidence: magnitude, comparability, time trends. Acta Neurol Scand 1991;84:382-8.

61 Ritchie K, Kildea D. Is senile dementia "age-related" or ageing-related"? - evidence from meta-analysis of dementia prevalence in the oldest old. Lancet 1995;346: 931-4.

62 Larsen JP and the Norwegian Study Group of Parkinson's disease in the elderly. Parkinson's disease as community health problem: study in Norwegian nursing homes. BMf 1991;303:741-3.

$63 \mathrm{Li} \mathrm{S}$, Schoenberg BS, Wang C, et al. A prevalence survey of Parkinson's disease and other movement disorders in the People's Republic of China. Arch Neurol 1985;42: 655-7.

64 Morgante L, Rocca WA, Di Rosa AE, et al. Prevalence of Parkinson's disease and other types of parkinsonism: a door-to-door survey in three Sicillian municipalities. Neurology 1992;42:1901-7.

65 Bharucha NE, Bharucha EP, Bharucha AE, Bhise AV, Schoenberg BS. Prevalence of Parkinson's disease in the Parsi community of Bombay, India. Arch Neurol 1988; 45:1321-3.

66 Tison F, Dartigues JF, Dubes L, Zuber M, Alperovitch A, Henry P. Prevalence of Parkinson's disease in the elderly: a population study in Gironde, France. Acta Neurol Scand 1994;90:111-5.

67 Liberatos P, Link BG, Kelsey Л. The measurement of social class in epidemiology. Epidemiol Rev 1988;10: 87-121.

68 Marmot MG, Shipley MJ, Rose G. Inequalities in deathspecific explanations of a general pattern? Lance $1984 ; \mathbf{i}: 1003-6$

69 Office of Population Census and Surveys. Classification of occupations. London: HMSO, 1980

70 McKeigue PM, Marmot MG. Epidemiology of Parkinson's disease. In: Stern G, ed. Parkinson's disease. London: Chapman and Hall, 1989:295-306.

71 Breslow NE, Day NE. Statistical methods in cancer research: Volume 2-the design and analysis of cohort studies. Lyon: IARC: 1987.

72 Kessler II. Epidemiologic studies of Parkinson's disease. III. A community based survey. Am f Epidemiol 1972 96:242-54

73 Martilla RI, Rinne UK. Arteriosclerosis, hereditary and some previous infections in the aetiology of Parkinson's disease. A case control study. Clin Neurol Neurosurg disease. A case

74 Stern M, Dulaney E, Gruber SB, et al. The epidemiology of Parkinson's disease: a case-control study of young onset and old-onset patients. Arch Neurol 1991;48. 903-7.

75 Semchuck KM, Love EJ, Lee RG. Parkinson's disease and exposure to agricultural work and pesticide chemicals. Neurology 1992;42:1328-35.

76 Mayeux R, Tang MX, Marder K, Cote LJ, Stern Y. Smoking and Parkinson's disease. Mov Disord 1994;9: 207-12.

77 Butterfield PG, Valanis BG, Spencer PS, Lindeman CA, Nutt JG. Environmental antecedents of young Nutt JG. Environmental antecedents of 1993;43. $1150-8$.

78 Bharucha NE, Stokes L, Schoenberg BS, et al. A casecontrol study of twin pairs discordant for Parkinson's control study of twin pairs discordant for Parkinson's disease: a search for

79 Grandinetti A, Morens DM, Reed D, MacEachern D. Prospective study of cigarette smoking and the risk of developing idiopathic Parkinson's disease. $\mathrm{Am} f$ Epidemiol 1994;139:1129-38.

$80 \mathrm{Ho}$ SC, Woo J, Lee CM. Epidemiologic study of Parkinson's disease in Hong Kong. Neurology 1989;39: 1314-8.

81 Hubble JP, Cao T, Hassanein RE, Neuberger JS, Koller WC. Risk factors for Parkinson's disease. Neurology 1993;43:1693-7.

82 Wong GF, Gray CS, Hassanein RS, Koller WC Environmental risk factors in siblings with Parkinson's disease. Arch Neurol 1991:48:287-9.

83 Koller W, Vetere-Overfield B, Gray C, et al. Environmental 1990;40:1218-21.

84 Barbeau A, Roy M, Bernier G, Campanella G, Paris S. Ecogenetics of Parkinson's disease: prevalence and envi- 
ronmental aspects in rural areas. Can $\mathcal{f}$ Neurol $\mathrm{Sci}$ 1987;14:36-41.

85 Golbe LI, Farrell TM, Davis PH. Follow-up study of early-life protective and risk factor

86 ease. Mov Disord 1990;5:66-70.

Ohlson C, Hogstedt C. Parkinson's disease and occupational exposure to organic solvents, agricultural chemicals and mercury-a case-referent study. Scand $\mathcal{f}$ Work Environ Health 1981;7:252-6.

87 Jimenez-Jimenez FJ, Mateo D, Gimenez-Roldan S Exposure to well water and pesticides in Parkinson's disease: a case-control study in the Madrid area. Mov Disord 1992; 7:149-52.

88 Ngim C, Devathasan G. Epidemiologic study on the association between body burden mercury level and idiopathic Parkinson's disease. Neuroepidemiology 1989;8: 128-41.

89 Aquilonius SM, Hartvig P. A Swedish county with unexpectedly high utilization of an

90 Wangl Scand 1986;74:379-82. $\mathrm{M}$, Jiang DH in ZJ A case-control study on the environmental risk factors of Parkinson's disease in Tianjin, China. Neuroepidemiology 1993;12:209-18.

91 Ebmeier KP, Mutch WJ, Calder SA, Crawford JR, Stewart L, Besson JO. Does idiopathic Parkinsonism in Aberdeen follow intrauterine influenza? $\mathcal{f}$ Neurol Neurosurg Psychiatry 1989;52:911-3.

92 Baumann RJ, Jameson HD, McKean HE, Haack DG, Weisberg LM. Cigarette smoking and Parkinson disease: 1. A comparison of cases with matched neighbours. Neurology 1980;30:839-43.

93 Godwin-Austen RB, Lee PN, Marmot MG, Stern GM. Smoking and Parkinson's disease. If Neurol Neurosurg Psychiatry 1982;45:577-81.

94 Kondo K. Epidemiological evaluations of risk factors in Parkinson's disease. Adv Neurol 1987;45:289-93.

95 Semchuk KM, Love EJ, Lee RG. Parkinson's disease: a test of the multifactorial etiologic hypothesis. Neurology 1993;43:1173-80.

96 Nefzger MD, Quadfasel FA, Karl VC. A retrospective study of smoking in Parkinson's disease. Am F Epidemiol 1968;88:149-58.

97 Martilla RJ, Rinne UK. Smoking and Parkinson's disease. Acta Neurol Scand 1980;62:322-25.

98 Haack DG, Baumann RJ, McKean HE, Jameson HD, Turbek JA. Nicotine exposure and Parkinson disease. Am $\mathcal{f}$ Epidemiol 1981;114:191-9.

99 Rajput AH, Offord KP, Beard CM, Kurland LT. A casecontrol study of smoking habits, dementia, and other illnesses in idiopathic Parkinson's disease. Neurology 1987;37:226-32.

100 Jimenez Jimenez FJ, Mateo D, Gimenez Roldan S. Premorbid smoking, alcohol consumption, and coffee
drinking habits in Parkinson's disease: a case-control drinking habits in Parkinson's dise
study. Mov Disord 1992;7:339-44.

$101 \mathrm{Kahn}$ HA. The Dorn study of smoking and mortality among U.S. Veterans: report on eight and one-half years of observation. Nat Cancer Inst Monogr 1966;19: 1-125.

102 Hammond EC. Smoking in relation to the death rates of one million men and women. In: Haenzel $W$, ed. Epidemiological approaches to the study of cancer and other chronic diseases. Bethesda, MD: National Cancer Institute, 1966:127

103 Doll R, Peto R, Wheatley K, Gray R, Sutherland I. Mortality in relation to smoking: 40 years' observations on male British doctors. BMF 1994;309:901-11.

104 Sasco AJ, Paffenbarger RSJ. Smoking and Parkinson's disease. Epidemiology 1990;1:460-5.

105 Poewe W, Karamat E, Kemmler GW, Gerstenbrand F. The premorbid personality of patients with Parkinson's disease: a comparative study with healthy controls and patients with essential tremor. Adv Neurol 1990;53: 339-42.

106 Eatough VM, Kempster PA, Stern GM, Lees AJ. Premorbid personality and idiopathic Parkinson's disease. Adv Neurol 1990;53:335-7.

107 Ward CD, Duvoisin RC, Ince SE, Nutt JD, Eldridge R, Calne DB. Parkinson's disease in 65 pairs of twins and in a set of quadruplets. Neurology 1983;33:815-24.

108 Williams DB, Annegers JF, Kokmen E, O'Brien PC, Kurland LT. Brain injury and neurologic sequelae: a cohort study of dementia, parkinsonism, and amycohort study of dementia, parkinsonism, and 7 .

109 Semchuck KM, Love EJ, Lee RG. Parkinson's disease and exposure to rural environmental factors: a population based case-control study. Can $₹$ Neurol Sci 1991;18: based case-86.

110 Golbe LI, Farrell TM, Davis PH. Case-control study of early life dietary factors in Parkinson's disease. Arch Neurol 1988;45:1350-3.

111 Tanner CM, Chen B, Cohen JA, et al. Dietary antioxidant vitamins and the risk of developing Parkinson's disease. Neurology 1989;39:181

112 Cerhan JR, Wallace RB, Folsom AR. Antioxidant intake and risk of Parkinson's disease (PD) in older women. $\mathrm{Am}$ f Epidemiol 1994;139:S65.

113 Lang AE, Marsden CD, Obeso JA, Parkes JD. Alcohol and Parkinson disease. Ann Neurol 1982;12:254-6.

114 Langston JW, Ballard P, Tetrud JW, Irwin I. Chronic parkinsonism in humans due to a product of meperidineanalog synthesis. Science 1983;219:970-80.

115 Tanner CM, Langston JW. Do environmental toxins cause
Parkinson's disease? A critical review. Neurology 1990; 40:suppl 30.

116 Sanchez-Ramos JR, Hefti F, Weiner WJ. Paraquat and Parkinson's disease. Neurology 1987;37:728.

117 Blair A, Zahm SH. Patterns of pesticide use among farmers: implications for epidemiologic research. Epidemiology 1993;4:55-62.

118 Stephens R, Spurgeon A, Calvert IA, et al. Neuropsychological effects of long-term exposure to organpsychological effects of long-term exposure to orga

119 Robins AH. Depression in patients with parkinsonism. Brf Psychiatry 1976;128:141-5.

120 Cummings JL. Depression and Parkinson's disease: a review. Am f Psychiatry 1992;149:443-54.

121 Yesalis CEI, Lemke JH, Wallace RB, Kohonut FJ, Morris MC. Health status of the rural elderly according to farm work history: the Iowa $65+$ rural health study. Arch Environ Health 1985;40:245-50.

122 Tanner C. Abnormal liver enzyme-mediated metabolism in Parkinson's disease: a second look. Neurology 1991;41:89-91.

123 Steventon GB, Heafield MTE, Waring RH, Williams AC. Xenobiotic metabolism in Parkinson's disease. Neurology 1989;39:883-7.

124 Steventon GB, Heafield MTE, Sturman SG, Waring RH, Williams AC, Ellingham J. Degenerative neurological Williams AC, Ellingham J. Degenerative neurological Medical Science Research 1989;17:163-4.

125 Armstrong M, Daly AK, Cholerton S, Bateman DN, Idle JR. Mutant debrisoquine hydroxylation genes in Parkinson's disease. Lancet 1992;339:1017-8.

126 Smith CAD, Gough AC, Leigh PN, et al. Debrisoquine hydroxylase gene polymorphism and suceptibility to Parkinson's disease. Lancet 1992;339:1375-7.

127 Agid Y. Parkinson's disease: pathophysiology. Lancet 1991;337:1321-3.

128 Elizan TS, Madden DL, Noble GR, et al. Viral antibodies in serum and CSF of parkinsonian patients and controls. Arch Neurol 1979;36:529-34.

129 Martilla RJ, Arstila P, Nikostelainen J, Halonen PE, Rinne UK. Viral antibodies in the sera from patients with UK. Viral antibodies in the sera from patient
Parkinson's disease. Eur Neurol 1977;15:25-33.

130 Schwartz J, Elizan TS. Search for viral particles and virusspecific products in idiopathic Parkinson disease brain material. Ann Neurol 1979;6:261-3.

131 Martyn CN, Cruddas M, Compston DA. Symptomatic Epstein-Barr virus infection and multiple sclerosis. $\mathcal{F}$ Neurol Neurosurg Psychiatry 1993;56:167-8.

132 Riggs JE. Cigarette smoking and Parkinson disease: the illusion of a neuroprotective effect. Clin Neuropharmacol 1992;15:88-99.

133 Ben-Shlomo Y. Smoking and neurodegenerative diseases. Lancet 1993;342:1239.

134 Yong VW, Perry TL. Monoamine oxidase B, smoking and Parkinson's disease. $\mathcal{F}$ Neurol Sci 1986;72:265-72.

135 Jenner $P$. Oxidative damage in neurodegenerative disease. Lancet 1994;344:796-8.

136 Smith PR, Cooper JM, Govan GG, Harding AE, Schapira AHV. Smoking and mitochondrial function: a model for AHV. Smoking and mitochondrial function: a mod
environmental toxins. $Q \mathcal{F}$ Med 1993;86:657-60.

137 Gresham LS, Molgaard CA, Smith RA. Induction of cytochrome $P-450$ enzymes via tobacco smoke: a potential mechanism for developing resistance to environmental toxins as related to parkinsonism and other neurologic diseases. Neuroepidemiology 1993;12:114-6.

138 Golbe LI, Cody RA, Duvoisin RC. Smoking and Parkinson's disease: search for a dose-response relationship. Arch Neurol 1986;43:774-80.

139 Eysenck HJ, Tarrant M, Woolf M, England L. Smoking and personality. $B M \mathcal{F} 1960 ; \mathbf{i}: 456-60$.

140 Forgays DG, Bonaiuto P, Wrzesniewski K, Forgays DK. Personality and cigarette smoking in Italy, Poland and Personality and cigarette smoking in Italy, Pola

141 Plassman BL, Helms MJ, Welsh KA, Saunders AM Breitner JCS. Smoking, Alzheimer' disease and confounding with genes. Lancet 1995;345:387.

142 Godwin Austen RB, Lee PN, Marmot MG, Stern GM Smoking and Parkinson's disease. $f$ Neurol Neurosurg Psychiatry 1982;45:577-81.

143 Raphael K. Recall bias: a proposal for assessment and control. Int $千$ Epidemiol 1987;16:167-70.

144 Weiss N. Should we consider a subject's knowledge of the etiologic hypothesis in the analysis of case-control studies? Am 7 Epidemiol 1994;139:247-9.

145 Rajput AH, Utti RJ, Stern W, Laverty W. Early onset Parkinson's disease in Saskatchewan - environmental considerations for etiology. Can $\mathcal{f}$ Neurol Sci 1986;13: 312-6.

146 Martyn CN. Choosing cases and controls in neurological research. $\mathcal{F}$ Neurol Neurosurg Psychiatry 1990;53:453-4.

147 Besearch. f Neurol Neurosurg Psychiatry 1990;53:453-4. Health services access and use among older adults in North Carolina: urban vs rural residents. Am 7 Public Health 1995;85:1384-90.

148 Rybicki BA, Johnson CC, Gorell JM. Demographic differences in referral rates to neurologists of patients with suspected Parkinson's disease: implications for case-control study design. Neuroepidemiology 1995;14:72-81.

149 Schlesselman J. Case-control studies: design, conduct, analysis. New York: Oxford University Press, 1982:1-354.

150 Granieri E, Carreras M, Casetta I, et al. Parkinson's disease in Ferrara, Italy, 1967 through 1987. Arch Neurol 1991;49:854-7.

151 Phillips AN, Davey Smith G. How independent are "independent" effects? Relative risk estimation when corre- 
lated exposures are measured imprecisely. $f$ Clin Epidemiol 1991;44:1223-31.

152 Rajput AH, Uitti RJ, Stern W, et al. Geography, drinking water chemistry, pesticides and herbicides and the etiolog of Parkinson's disease. Can $\mathcal{F}$ Neurol Sci 1987;14:414-8.

153 Spencer P. Guam ALS/Parkinsonism-dementia: a longlatency neurotoxic disorder caused by "slow toxin(s)" in food? Can $\mathcal{F}$ Neurol Sci 1987;14:347-57.

154 Willett W. Overview of nutritional epidemiology. In: Willett W. Overview of nutritional epidemiology. In:
W, ed. Nutritional epidemiology. New York: Willett W, ed. Nutritional epidemiolo

155 Dwyer JT, Gardner J, Halvorsen K, Krall EA, Cohen A, Valadian I. Memory of food intake in the distant past. Am ₹ Epidemiol 1989;130:1033-46.

156 The Parkinson Study Group. Effects of tocopherol and deprenyl on the progression of disability in early Parkinson's disease. N Engl f Med 1993;328:176-83.

157 Marttila RJ, Rinne UK. Arteriosclerosis, heredity, and some previous infections in the etiology of Parkinson's disease. A case-control study. Clin Neurol Neurosurg 1976;79:46-56.

158 Hoehn MMM. Parkinson's disease: progression and mortality. Adv Neurol 1986;45:457-61.
159 Marmot MG. Mortality and Parkinson's disease. In: Rose FC, Capildeo R, eds. Research progress in Parkinson's disease. London: Pitman, 1988;9-16.

160 Rajput AH, Offord KP, Beard CM, Kurland LT. A casecontrol study of smoking habits, dementia, and other illnesses in idiopathic Parkinson's disease. Neurology 1987 ; 37:226-32.

161 Di Monte D, Sandy MS, Blank L, Smith MT. Fructose prevents 1-methyl-4-phenyl-1,2,3,6-tetrahydropyridine prevents 1-methyl-4-phenyl-1,2,3,6-tetrahydropyridine hepatocytes. Biochem Biophys Res Commun 1988;153: hepatocytes.

162 Moller H, Mellemkjaer L, McLaughlin JK, Olsen JH. Occurence of different cancers in patients with Parkinson's disease. BMF 1995;310:1500-1.

163 Barbeau A, Joly JG. Parkinson et cancer. Union Med Can 1963;92:169-74.

164 Jansson B, Jankovic J. Low cancer rates among patients with Parkinson's disease. Ann Neurol 1985;17:505-9.

165 Barrett-Connor E. Are we living longer or dying longer? In: Poulter N, Sever P, Thom S, eds. Cardiovascular disease: risk factors and intervention. Oxford: Radcliffe Medical risk factors and inter 